\title{
Employers' liens on pension benefits
}

Received: 11th February, 2002

\section{David Pollard}

is a partner specialising in pensions and employment law at Freshfields Bruckhaus Deringer. He is currently chairman of the Association of Pension Lawyers (APL). His book, 'Corporate Insolvency: Employment and Pension Rights', was published by Butterworths in 2000.

\begin{abstract}
This paper, based on a talk given to the APL in February 2002, summarises the legal position on employer lien clauses in occupational pension schemes.

The legislation allows occupational schemes to include a provision for a charge or lien on scheme benefits in favour of an employer where the member owes a debt obligation of a particular kind to an employer. The debt must arise from a fraudulent, criminal or negligent act or omission of the member. The paper looks at the limitations on these clauses, the tax effect and the relevant case law.
\end{abstract}

Keywords: employer lien, employer charge, S91, Pensions Act 1995, forfeiture

\section{General rule: No charge or lien over of benefits}

The general rule is that a person's accrued right to a pension cannot be assigned or charged (s91(1), Pensions Act 1995). This limitation applies to all occupational pension schemes including schemes without revenue approval. ${ }^{1}$

There are some limited exceptions eg covering directors granting security over their benefits to secure loans made to the employer. ${ }^{2}$ These are not dealt with further.

One of the exceptions to this is that person's rights or entitlements may be subject to a charge or lien to enable the employer to recover sums arising out of a criminal, negligent or fraudulent act or Deringer, 65 Fleet Street, London EC4Y 1HS, UK.

Tel: +44 (0)20 7832 7060; Fax: +44 (0)20 7832 7636; email: david.pollard@ freshfields.com omission by the person $(\mathrm{s} 91(5)(\mathrm{d}))$.

\section{What is covered by the lien}

The person must owe money to the employer (not another group company).
Clearly there must be an act or omission involving:

- a crime

- fraud

- negligence.

It is not enough that the member may owe money (eg on a loan account) to the employer. It cannot be said to be 'negligent' of the member to fail to pay the money when it is due. ${ }^{3}$

Obviously a criminal act in the UK will be enough. What about a crime abroad? It is possible that this should be enough, even if the relevant act or omission is not a crime in the UK. ${ }^{4}$

The term 'fraud' is not defined. However, it seems likely that it will have its general meaning of dishonesty (and not include extended concepts such as equitable fraud for failure to comply with a particular purpose).$^{5}$

It seems that costs (eg legal fees) and 
interest on the amount originally owing are also recoverable under the lien. This would be on the basis that they are part of the 'monetary obligation' due from the member 'arising out of' the relevant act or omission. This may depend on whether such costs or interest are in fact legally due if court proceedings were not commenced. On balance, the author considers that they are recoverable if agreed with the member or if of the same amount as would be awarded by a court.

\section{Conditions}

Various conditions are laid down in section 91 . Where a charge or lien is exercised then, under s91(6):

(a) it must not exceed the lesser of the monetary obligation or the person's accrued rights/entitlement;

(b) the person must be given a certificate showing:

(i) the amount of the charge; and

(ii) the effect of this on the benefits.

If the charge/lien is disputed, then it cannot be exercised unless the obligation has become enforceable under a court order or award of an arbitrator.

\section{Pensions Act 1995, s92 and s93}

Generally, an entitlement or accrued right to a pension cannot be forfeited (s92). One of the exceptions to this is that forfeiture of a person's entitlement by reference to a person having incurred some monetary obligation to the employer arising out of a criminal, negligent or fraudulent act or omission is permitted (s93(1)).

The trustees can determine that the amount forfeited may be paid to the employer (s93(5)). In practice unless they did so, the effect would be that the employee's debt owed to the employer would not be reduced. ${ }^{6}$

\section{Trust deed}

There needs to be a lien rule actually in the trust deed. Sections 91 and 93 do not confer a statutory power, instead they do not prohibit a lien rule being included. If there is no lien rule in the scheme deed, then a lien cannot be exercised (unless perhaps the member and the trustees agree to an effective amendment).

It may be possible to insert a lien rule by amendment. This may not be possible if the amendment power prohibits amendments which allow payments to the employer. ${ }^{7}$

If the amendment power does allow such an amendment, it will not be within the limits under section 67 of the Pensions Act 1995. Amendments to include lien rules which comply with sections 91 to 94 are excluded from section 67 - see regulation 6(1) of the Occupational Pension Schemes (Modification of Schemes) Regulations 1996 (SI 1996/2517, as amended by SI 1999/3198).

There is a statutory power, in section 68 of the Pensions Act 1995, for trustees to amend a scheme 'to enable the scheme to conform with section...91 or 92'. However, in the author's view this probably does not allow a lien rule to be included. Instead an existing rule can be cut down so as to comply with those sections.

\section{Transfer credits}

There is a limitation on the transfer credits that can be subject to a lien.

A member may bring a transfer from an entirely unconnected employer into the scheme (eg following a change of 
job). In exchange benefits are granted in the receiving scheme, called 'transfer credits'. Understandably, it would often not be fair for any lien in favour of the current employer to cover such transfer credits - the current employer would not have been able to exercise a lien over the benefits if left behind in the transferring scheme.

However, if the transfer is from a connected scheme, (eg on a scheme merger), it is fair to allow the lien to apply.

Before 1997, an application would have to be made to the OPB for an exemption from the preservation requirements to cover this point. ${ }^{8}$ Since 5th April, 1997, section 91 now deals with this by providing that generally a lien cannot apply to transfer credits. There is an exception, however, for 'prescribed transfer credits'. These are defined as

'those transfer credits attributable to employment with the same employer or an associated employer and the benefits of which could have been charged or a lien or set-off exercised in respect of such benefits under the occupational pension scheme from which the transfer was made.'

Regulation 3 of the Occupational Pension Schemes (Assignment, Forfeiture, Bankruptcy etc.) Regulations 1997 (SI 1997/785).

An associated employer is widely defined in section 435 of the Insolvency Act $1986^{9}$ (eg it will cover companies in the same group).

Broadly, the exemption allows a lien over transfer credits to the extent there was a lien in the transferring scheme. It is not clear if the lien in the receiving scheme can be wider than that in the transferring scheme. In practice it is safest if the lien in the receiving scheme is limited to cover the same amounts as would have been covered in the transferring scheme (eg if the transferring scheme only had a lien covering crime, this should not be extended in the receiving scheme to cover fraud or negligence).

As noted, generally regulation 3 should be sufficient to catch transfers when made within a group. However, it seems that the regulation may not cover the position where the transfer credit had been from an employer where there has been a transfer of the business from outside the group.

Take the situation where a transfer of business is made (a TUPE transfer) from $A$ to $B$ ( $A$ and $B$ are not in the same group). An employee employed by $A$ in the relevant business will be transferred under TUPE to B. If he leaves A's pension scheme at the same time as the TUPE transfer and then immediately joins B's pension scheme, the relevant transfer credits will not be prescribed within regulation 3 . This is because employment with $\mathrm{A}$ is not employment with an associated employer of B.

Expanding the scenario slightly further, does the position alter if $\mathrm{B}$ in fact participates in A's scheme for an interim period and then sets up its own scheme? Will the resulting transfer credit (from the transfer from A's scheme to B's scheme) be prescribed in regulation 3 ?

At the stage of transfer of the pension benefits, there will be a transfer from A's scheme (in which B then participates) to B's scheme. Clearly, not all the transfer credits are 'attributable to employment with the same employer or an associated employer'. Most will relate to the previous employment with A. But some of the credits (those that relate to the interim period) will relate to employment with B. Is this enough? Would some apportionment be necessary? ${ }^{10}$

Generally the regulations would be better drafted if: 
- reference to associated were expanded to include TUPE transfers etc; there is a precedent for this in the regulations relating to continued rights for Inland Revenue purposes - see the definition of 'relevant employer' in the Retirement Benefits Scheme (Continuation of Rights of Members of Approved Schemes) Regulations 1990 (SI 1990/2101); and

- the reference to 'transfer credits attributable to employment with the same employers or associated employer' should be expanded by the addition of the words 'or attributable to a transfer from an occupational pension scheme in which the member qualified as an active member (immediately prior to his ceasing to be in pensionable service) by reason of his employment with the same employer or an associated employer'.

\section{Problems with the sections}

There are various problems with interpretation of sections 91 and 93. The author does not think that these stand in the way of an employer exercising a charge in a scheme.

\section{Amount recovered}

Both sections state that the amount recovered (or forfeited) must not exceed 'the amount of the monetary obligation in question or (if less) the value (determined in the prescribed manner) of the [person in question's] entitlement or accrued right'.

It has been argued that the wording in italics causes a difficulty as no manner has been prescribed (in regulations) by the relevant department (now the DWP, formerly the DSS).

The DSS certainly took the view that no regulations were needed. ${ }^{11}$

However, the author interprets the wording as allowing a charge to be exercised. In effect, I consider that the wording in italics can be ignored if there is no prescribed manner. In practice, I suggest that the value of the benefits are assessed by reference to the member's cash equivalent transfer value (in excess of the GMP and ignoring any transfer credits). This seems to be the most appropriate given that the member will (almost certainly) have been dismissed and become a deferred member.

Consider whether it would be more appropriate (eg in a forfeiture) in some cases to use the MFR instead. There may be a difference between the MFR and the cash equivalent (for example the MFR does not take account of discretionary benefits, but the cash equivalent usually does if it is an established practice).

\section{Member's benefits only?}

It has also been argued that only the Member's benefits can be charged, ie the employer would not be able to exercise a charge or lien over any spouse's or dependant's pension payable in respect of the Member. The Goode Committee recommended this. Various commentators suggested that the original wording of section 91(5) of the Pensions Act 1995 achieved this (by using the wording 'person in question').

However, the author's view was that the literal wording of the sections suggested that this was not correct. In my view section 124 is clear in defining the 'accrued rights' of a member to include the benefits "which have accrued to or in respect of him'. The words in bold indicate that pensions for spouse and dependants were covered (this interpretation has been endorsed by the DSS in comments on section 67 of the Pensions Act, which deals with amendment to accrued rights). 
However, the wording of both sections has been amended by the Welfare Reform and Pensions Act 1999 (with effect from 1st December, 2000). Section 91 now only allows a set-off or lien to apply to the 'entitlement or right' of the 'person in question' instead of to his or her 'accrued rights'. Section 93 dealing with forfeiture has been similarly amended.

It is not clear whether or not the 'entitlement or right' of a member will include the potential benefits of the relevant spouse and dependants as secondary beneficiaries. The author is not sure why the wording was changed. This seems to leave the prospect of a member committing a criminal act and having his pension forfeited, but leaving a pension payable to his spouse and dependants. This seems rather odd.

\section{Exercising a lien: Section 67?}

Section 67 of the Pensions Act 1995 generally prohibits the exercise of powers which modify a scheme and which affect any entitlement or accrued right of a member. Generally, the author considers that section 67 does not apply to the exercise of an existing charging or forfeiture power (on the basis that it is not a modification to the scheme).

However, he is aware that doubts on this point have been expressed.

In practice, it would be helpful if the approval of the trustees and the written consent of the member to the exercise of the charge and the forfeiture can be obtained (as section 67 will then have been satisfied).

\section{Contracted-out benefits: pension schemes act 1993, S159}

Any assignment or charge over GMPs and protected rights are void. Forfeiture is also only allowed in limited circumstances (see OPB model rule 17 for GMPs).

There is no equivalent statutory protection for section $9(2 \mathrm{~B})$ rights (ie benefits after 6th April, 1997 in a scheme which is contracted out on a salary-related basis). In practice it seems that actuaries are still willing to give the required certificate that the benefits under the scheme comply with the statutory reference scheme test - they are not requiring any exclusion from forfeiture or lien rules (presumably concluding that this falls within the 10 per cent allowance of members who could receive less than the reference scheme standard).

\section{Transfer rights}

Deferred pensioners in a pension scheme have a statutory right to a transfer payment out of the scheme. This arises under sections 93 to 101 of the Pension Schemes Act 1993 (as amended).

In effect a member can ask for a quote to be given of a guaranteed cash equivalent transfer amount. Following this, the member can then direct the trustees to transfer that amount to a relevant receiving arrangement (if the scheme is Revenue approved, the receiving arrangement must be a Revenue approved personal pension or occupational pension scheme etc.).

Obviously the effect of such a transfer would be to cancel the charge held by the company over the member's benefits (or perhaps transfer it to the receiving scheme - see below).

Section 101 of the 1993 Act makes it clear that when making calculations any relevant charge or lien is to be disregarded.

Once a member has received a guarantee and exercised his option to require a transfer, the trustees generally have six months in which to make the 
relevant transfer (section 99(2), PSA

1993).

However section 99(3) goes on to state:

(3) If:

(a) disciplinary proceedings or proceedings before a court have been begun against a member of an occupational pension scheme at any time before the expiry of the period of 12 months beginning with the termination date; and

(b) it appears to the trustees or managers of the scheme that the proceedings may lead to the whole or part of the pension or benefit in lieu of a pension payable to the member or his widow being forfeited; and (c) the date before which they would (apart from this subsection) be obliged under subsection (2) to carry out what the member requires is earlier than the end of the period of 3 months after the conclusion of the disciplinary or court proceedings (including any proceedings on appeal),

then, subject to the following provisions of this section, they must instead do so before the end of that period of 3 months.

This is a slightly odd section. It requires proceedings to have been brought against the member within 12 months 'beginning with the termination date'. The term 'termination date' is no longer defined in the 1993 Act (although it was in the original section 93(1)(a) as the date on which pensionable service ceased).

It is not clear what are 'disciplinary' proceedings for the purpose of this section. ${ }^{12}$

In the author's view, a simple debt claim (which would not fall within a line rule) is probably enough for this purpose, (presumably any claim that did fall within a lien rule could be asserted by way of an amendment to the proceedings). It seems that section 99(3)(a) is wide enough to encompass such amended proceedings.

The wording of section 99(3)(b) is fairly broad: "If it appears to the trustees... that 'the proceedings may lead to the whole or part of the pension... being forfeited'.

This seems to be based on a mere possibility rather than necessarily the trustees taking a view as to the likelihood of success.

The point has been made ${ }^{13}$ that section 99(3)(b) only refers to forfeiture. It does not refer to a charge or lien. However it seems that it is arguable that either:

- forfeiture in this context includes a charge or lien; or (alternatively)

- charges or liens do not fall within section 99(3) at all. The effect is that as a matter of general law no transfer payments should be made if a charge or lien is asserted (even if proceedings are not brought within 12 months). Instead there should be a suspense account. This could be supported by the decision of Vinelott J. in Haque $v$. Bevis Trustees Ltd [1996] OPLR 271 (see below).

This would be supported by the fact that the 12-month rule in section 99(3)(a) causes odd results. If for some reason the provision applied so that the member still had a statutory transfer right even though there were a set off/charge asserted, the effect of section 99(6) (that the charge cannot be asserted prior to a court order) would mean that it would always be possible for the member to escape the charge by making a transfer.

This seems a ludicrous result (which could perhaps be avoided by assuming that section 99(3) does not apply to 
charges or that the charge follows the member's benefit into the receiving scheme - this seems a more messy result).

\section{Payment of benefit}

There is no express provision in the 1995 Act dealing with a situation where the member requests a benefit in circumstances where a charge is being asserted.

However, in Haque v. Bevis Trustees Ltd [1996] OPLR 271, Vinelott J. held that it would be the responsibility of trustees in these circumstances to pay pensions into a suspense account while the matter was sorted out. Although this was partly on the basis of a particular provision in the rules of the scheme concerned (the BCCI Pension Scheme), the more general position was taken that it would be unfair on an employer to allow the member to take a transfer-out or to start to draw benefits (including commutation to a lump sum). Vinelott J commented (at page 275):

'Under rule 8 a member has a right in certain circumstances to commute a portion of his pension for a lump sum not exceeding a maximum calculated by reference to a formula there set out. Mr Haque [the member] exercised that right before a claim had been notified to the trustee by the joint liquidators and the sum payable on commutation was paid to him. If Mr Ellis's [counsel for Mr Haque] submissions were well founded, the right would be exercisable even after the claim had been notified. The employer would be powerless to prevent the trustee from paying the sum due on surrender. The employer's right of recovery might be prejudiced even if the employee had been dismissed because he had, for example, misappropriated moneys belonging to the employer.'

The case has been criticised (not least because there is no reference to section
99(3)). One argument used by the member was that it was in fact more appropriate for an employer to seek a Mareva injunction against the member in these circumstances restraining him from claiming payment of the pension.

Vinelott J. thought that this would be an unnecessary complication.

\section{Mareva injunctions?}

In support of Vinelott J's holding, it should also be noted that, since this case, section 91(2) of the Pensions Act 1995 has come into force. This came into force on 6th April, 1997 and states that:

'(2) Where by virtue of this section a person's entitlement, or accrued right, to a pension under an occupational pension scheme cannot, apart from subsection (5), be assigned, no order can be made by any court the effect of which would be that he would be restrained from receiving that pension.'

The effect of this section would seem to be that it may not no longer be possible for the court to grant a Mareva injunction against an individual member in these circumstances. The full ambit of this section has yet to be tested in the courts. ${ }^{14}$

In practice if the member sought to exercise his or her transfer rights (or a right to draw a pension) a cautious approach would be for the trustees to either:

- bring the matter to court themselves (ie inter-plead) seeking directions; and/or

- perhaps protect their position on transfer by looking for an extension of time from the Occupational Pensions Regulatory Authority (OPRA).

Section 99(4) of PSA 1993 allows Opra 
to give extension of time to trustees in prescribed circumstances. These grounds are set out in Regulation 13 of the Occupational Pension Schemes (Transfer Values) Regulations 1996 (SI 1996/1847). They are:

(13) Extension of time limits for payment of cash equivalents

The Regulatory Authority may grant an extension of the period mentioned in section 99(2)(a) or, as the case may be, (b) of the 1993 Act (trustees' duties after exercise of option) if the trustees have within that period applied to the Regulatory Authority for an extension and -

(a) the Regulatory Authority is satisfied that:

(i) the scheme is being wound up or is about to be wound up,

(ii) the scheme is ceasing to be a contracted-out scheme,

(iii) the interests of the members of the scheme generally will be prejudiced if the trustees do what is needed to carry out what is required within that period,

(iv) the member has not taken all such steps as the trustees can reasonably expect in order to satisfy them of any matter which falls to be established before they can properly carry out what the member requires,

(v) the trustees have not been provided with such information as they reasonably require properly to carry out what the member requires, or (vi) the member's guaranteed cash equivalent has been reduced or increased under regulation 9 or the member has disputed the amount of the cash equivalent;

(b) the provisions of section 53 of the 1993 Act (supervision of formerly certified schemes) apply; or (c) an application has been made for an extension on a ground specified in paragraph (a) or (b) and the Regulatory Authority's consideration of the request cannot be completed before the end of that period.'

None of these circumstances expressly relate to the exercise of a charge or lien (unless it could be said that (a)(vi) applies on the basis that the member disputes the amount of the charge or lien and hence the transfer value).

There is a cross reference to regulation

9. The relevant parts state:

(9) Increases and reductions of guaranteed cash equivalents

(1) This regulation applies to a guaranteed cash equivalent when a statement of entitlement has been sent to a member of a salary related scheme by the trustees of the scheme.

(2) Where all or any of the benefits to which a guaranteed cash equivalent relates have been surrendered, commuted or forfeited before the date on which the trustees do what is needed to carry out what the member requires, that part of the guaranteed cash equivalent which relates to the benefits so surrendered, commuted or forfeited shall be reduced to nil.

$\cdots$

(6) In a case where two or more of the paragraphs of this regulation fall to be applied to a calculation, they shall be applied in the order in which they occur in this regulation except that where paragraph (5) falls to be applied it shall be applied as at the date on which it is established that the guaranteed cash equivalent falls short of or exceeds the proper amount.'

Regulation 9(2) refers to the cash equivalent being reduced to nil if the benefits have been 'surrendered, commuted or forfeited'. This seems to mean that it only applies after forfeiture has actually occurred (rather than when it is simply pending). ${ }^{15}$ There is also the question about whether forfeiture in 
these circumstances includes a charge or lien.

Regulation 13(a)(iii) refers to the interest of the members of the scheme generally being prejudiced. It is clear that this refers to monetary prejudice of such members, rather than to any sense of outrage they may have based on the transfer value actually going ahead. See on this the decision of Lightman J. in $R$ v. OPRA ex parte Littlewoods [1998] PLR 63 (see below).

In practice, the trustees would probably be well advised if the dispute arose to apply to OPRA for an extension, although it seems to me that they may not in fact have power to grant it (unless regulation 13(a)(vi) on disputes could be said to apply). This may force the trustees to go down the inter-pleading route by applying to Court.

\section{Tax}

\section{Charge on the employer: ICTA, s601}

Generally there is a free-standing 35 per cent tax charge ${ }^{16}$ payable by an employer on any payments made from an exempt approved scheme to an employer. This tax charge does not apply to any payment which the scheme administrator is obliged to make under a scheme provision which enables the employer to obtain the discharge of some monetary obligation due to the employer which arises out of a criminal, negligent or fraudulent act or omission by the member - s601(3), ICTA 1988 and regulation 4, Pension Scheme Surpluses (Administration) Regulations 1987 (SI 1987/352).

\section{Tax: Impact on employee}

If a lien is exercised, it seems that there is no tax charge on the employee. The employee will benefit in that the effect of the payment will be to discharge (or reduce) the debt otherwise owing from the employee to the employer. However, it seems likely that this is not treated as a taxable benefit in the hands of the employee (the position may differ if the payment is out of an unapproved scheme).

There may be an issue if payment of a benefit is suspended pending resolution of a dispute as to whether or not there is a lien. The note by Timothy Knight in the OPLR report of Haque v. Bevis Trustees [1997] OPLR 271 includes a discussion (page 279) of the tax position during the suspension. He hopes that no tax will be chargeable until a payment is actually made to the pensioner but wonders if this could mean that the pension (if ultimately paid) gets pushed into another tax year.

\section{Pensions Act 1995, s37: Restrictions on payments to employers}

This section sets out the conditions that have to be satisfied before payments can be made to an employer. These restrictions do not apply to amounts recovered under lien rules. This is because section 37 does not apply if there is a payment to an employer which is not (by virtue of s601(3), ICTA 1988) subject to s601(2), ICTA 1988 (see s37(7), PA 1995).

\section{Tax notifications}

There is no requirement for approved schemes to notify the Inland Revenue of the exercise of a lien rule.

Regulation 10 of the Retirement Benefits Schemes (Information Powers) Regulations 1995 (SI 1995/3103) requires the scheme administrator to notify the Revenue within 30 days of the relevant year end of 'any payment to an employer to which section 601 of the 
Taxes Act applies (charge to tax on payments to employer out of funds of an exempt approved scheme)'.

As mentioned above, payments under a lien rule are outside the tax charge, so the information obligation does not apply. This is confirmed by Note 5 on the return form, form 1 (SF) (3/97) (copy in IR12), which states that administrators should 'exclude any amounts which are paid to an employer to reimburse...any financial loss caused by the employee's fraud or negligence'.

\section{Trustee records}

Trustees of approved schemes are obliged to keep records of all payments made to an employer - regulation 12(1)(b)(ix) of the Occupational Pension Schemes (Scheme Administration) Regulations 1996 (SI 1996/1715). The records must be kept for at least six years (reg. 14).

\section{Unapproved schemes}

As mentioned above, the limits in ss 91 to 95 of the Pensions Act 1995 apply to all schemes, approved and unapproved. So any lien rule in an unapproved scheme will be subject to the same limits. In practice a lien will only apply in a funded unapproved scheme (FURBS). An unfunded promise has no asset to apply a lien over (although a forfeiture provision could apply).

But should an unapproved scheme have a lien rule at all? Could this have an adverse tax consequence? This could include:

- loss of the exemption from paying the higher rate of tax applicable to accumulation and discretionary trusts on the basis that the FURBS is not one which is established for the sole purpose of providing relevant benefits (s686(2)(c)(i), ICTA 1988);
- a tax charge on the amount paid out at the rate of 40 per cent (s596A, ICTA 1988). This section charges all payments out of unapproved schemes unless the exemption in s596A(8) is available. This exemption only applies to a lump sum paid to:

'the employee, an ex-spouse of the employee, any person falling within s595(5) in relation to the employee [i.e. generally spouse and dependants] or any other individual designated by the employee'

This exemption does not seem to apply to employers - if a corporate body, it would not seem to be possible to envisage a designation under the section (as the employer would not be an 'individual').

- It is perhaps possible that the inclusion of a lien rule could mean that the revenue decide that the scheme is not a retirement benefits scheme or that no tax deduction on payments into the FURBS should be available (on the basis that the payment could be refunded - see Goulding J in Rutter v. Charles Sharpe $\&$ Co [1979] STC 711). However this seems unlikely (given that lien rules are common in approved schemes).

The author wrote to the revenue some years ago on the tax issues, but it was obviously too complicated and there was no reply.

In practice lien rules are included in unapproved schemes. The points raised above in relation to taxation of discretionary trusts and to the FURBS being a retirement befits scheme do not seem to have been taken by the revenue - presumably because the lien rule mirrors a provision commonly 
found in approved schemes. I have not seen a rule exercised in an unapproved scheme. It may in practice be possible to persuade the revenue that no tax charge should apply (on the basis that no such charge is applied in relation to approved schemes).

The above arguments are less likely to apply in the case of a forfeiture rule. Here the amount forfeited could be left in the fund and used to meet future employer contributions for other members (although the impact of this on the tax exemption under s596A(8) would need to be considered).

\section{Data protection}

Details of the employer's claim against the member will usually be personal data protected by the Data Protection Act 1998. In practice, the data will be held by the employer and then shared with the trustees (and the relevant advisers). Is this allowed by the 1998 Act?

Broadly, personal data are only protected by the 1998 Act if they are held on a relevant electronic filing system or within a structured file. In practice this may well mean that if information is kept off the member's file (and not held electronically) it is not caught by the Act. However, there will be circumstances in which it appears on a file. Broadly, processing of personal data (eg that the employee has committed a negligent act etc.) should be allowed under the relevant principles in Schedule 2 to the 1998 Act. These include:

- Paragraph 3: this allows processing which is 'necessary for compliance with any legal obligation to which the data controller is subject, other than an obligation imposed by contract'. This could protect the trustee in relation to complying with its legal obligation to allow the employer to exercise a lien or charge

- Paragraph 6: this allows processing which is 'necessary for the purposes of legitimate interests pursued by the data controller or by a third party or parties to whom the data are disclosed, accept where the processing is unwarranted in any particular case by reason of prejudice to the rights and freedoms or legitimate interests of the data subject'. This seems to be wide enough to cover the legitimate interest of the employer in recovering amounts due from the member.

If the allegations against the employee relate to a crime, that fact will be 'sensitive personal data' within the 1998 Act. This is because it will be data relating to the commission or alleged commission of any offence or details of proceedings for any such offence (s2, DPA 1998).

Sensitive personal data is subject to additional risk and must only be processed in compliance with additional restrictions. These are set out in Schedule 3 to the 1998 Act. These seem to allow such processing:

- Paragraph 2: this allows processing which is 'necessary for the purposes of exercising or performing any right or obligation which is conferred or imposed by law on the data controller in connection with employment'.

Arguably this covers the exercise of a lien in the trust deed, although this depends on being able to categorise the lien as a right 'imposed by law';

- Paragraph 6: this allows processing which is necessary for the purposes of legal proceedings or obtaining legal advice or otherwise for the purposes of establishing, exercising or defending legal rights. This more clearly covers an employer's lien. 


\section{Human Rights Act}

The Human Rights Act 1998 came into force on 2nd October, 2000. Is the exercise of a lien by the employer in accordance with the Act?

An attempt was made in the bankruptcy case, Krasner v. Dennison [2001] Ch 76, to claim that the

Human Rights Act (then not in force) applied in a similar situation. This was a case about the vesting of pension rights in a trustee in bankruptcy on the bankruptcy of the member. The argument was made that this transfer of pension rights was contrary to Article 1 in the First Protocol to the European Convention on Human Rights (set out in Part II of Schedule 1 to HRA 1998).

This article provides that 'every natural legal person is entitled to the peaceful enjoyment of his possessions. No one should be deprived of his possessions except in the public interest and subject to the conditions provided for by law and by the general principles of international law'.

In Krasner v. Dennison the Court of Appeal rejected this argument, holding that the vesting of the pension in the trustee in bankruptcy was appropriate. It complied with conditions provided for by law. A similar analysis looks applicable in relation to an employer's charge or lien. Such charges or liens are regulated by the Pensions Act 1995 so the requirement for the conditions to be 'provided for by law' seem to be satisfied.

Broadly, if such a claim succeeded it would only be on the grounds that all liens and charges (eg mortgages securing house loans) are contrary to the Human Rights Act. It is very unlikely that the courts would hold this.

\section{Case law}

There has not been much case law on lien rules.
Haque v. Bevis Trustees Ltd [1996] OPLR 271.

A decision of Vinelott $\mathrm{J}$. The employer was claiming a charge under the lien rule in the scheme based on negligent, fraudulent or criminal acts. This was being disputed. Vinelott $\mathrm{J}$ held that it was appropriate for the trustees to suspend the payment of benefits pending resolution of the dispute.

The note by Timothy Knight in the OPLR report includes a discussion (p. 279) of the tax position during the suspension. He hopes that no tax will be chargeable until a payment is actually made to the pensioner but wonders if this could mean that the pension (if ultimately paid) gets pushed into another tax year.

\section{R v. OPRA ex parte Littlewoods [1998] PLR 63, [1997] OPLR 375.}

A decision of Lightman J. OPRA had refused to extend the time limit for making a transfer payment out of the scheme where the employer had requested this on the basis he would bring a claim against the employee. There was no lien rule in the Scheme, but the argument was that if the employer were successful he could make the employee bankrupt and this would result in the benefit being forfeited. Lightman J refused the application, holding that it seemed right and proper for OPRA to not agree to an extension of time in these circumstances.

Interestingly, Lightman J referred to the extension of time provisions in the transfer value legislation (this had not been mentioned by Vinelott $\mathrm{J}$ in the Haque case). There is no mention of the Haque case.

Note also the decision of Arden $\mathrm{J}$ in Norman v. Pensions Ombudsman [1997] OPLR 85 where forfeiture of a member's benefit was upheld. The 
employee had purported to charge his benefits as security for loans owed to the employer and another company (the employer's parent company).

\section{Haque v. BCCI [2000] 06 PBLR (10).}

This is the decision of the Court of Appeal given on 24th November, 1999. It deals with the actual claim by BCCI against $\mathrm{Mr}$ Haque for a set-off against his pension. The Court of Appeal held that the set-off was valid. The case discusses the standard of proof needed to establish a claim (holding that the member may have to rebuff a claim where prima facie evidence of fraud has been produced).

In addition, the limitation period did not start to run until the employer could have been expected to have discovered the fraud.

\section{Bank of England v. Gibson (1994) 26 April (Judge Rudd, sitting as a judge of the High Court) ${ }^{17}$}

This was a civil claim by the Bank of England against some former employees based on theft of money by them from the bank. The police had declined to prosecute. The bank sought to claim repayment of amounts stolen. Judgment was given in the bank's favour. Judge Rudd held that although allegations of theft were made, the civil standard of proof is applicable, ie

'the balance of probabilities, but that the degree of probability must be commensurate with the occasion and proportionate to the subject-matter. That is, there is a sliding scale as to probability according to the gravity of the subject matter.'

Hornal v. Neuberger [1957] 1 QB 247 (CA) was followed on this. Having obtained judgment, presumably the bank could then look to apply any lien that was in any relevant pension fund.

\section{Practical steps}

What practical steps should an employer take when faced with the situation of a potential lien over benefits?

- Check the ambit of the lien rule

- an actuary should certify the value of the Member's benefits (excluding any GMP or protected rights)

- A suitable person at the employer should provide a certificate (which he/she has signed) and which contains the following information:

(a) confirmation that there has been a criminal, fraudulent or negligent act or omission by the Member;

(b) the amount or value of the benefits being charged or, if less, the amount of the total debt or liability remaining owing to the employer in respect of that act this can be by attaching the actuary's certificate; and

(c) (perhaps) details of how the amount has been calculated.

- The certificate should be sent to the trustees.

- A copy of the certificate should be sent to the Member together with a statement detailing how any deduction will affect his benefits under the Plan (in practice, here, it will leave only the GMP payable). Exercise of the charge depends on the Member having received this notice. ${ }^{18}$ In practice, some evidence of proof of receipt by the Member is required perhaps by sending it by recorded delivery with receipt advised. It may not be safe to rely on any deeming provision for notices in the scheme rules.

- It would be prudent to ask the Member to confirm whether he disputes either the amount set out in the certificate or that he owes any debt or liability to the employer.

- If the Member does not dispute the 
claim or its quantum, ${ }^{19}$ then the trustees are required to deduct the amount certified from the Member's benefits. The relevant lien rule should be checked to see that it allows the charge to be exercised out of the fund before retirement ie not just from amounts which have actually become payable.

- Subject to any objection, the trustees should then pay the amount deducted to the employer.

- If the Member disputes either the claim or the amount he owes to the employer, then the employer will need to obtain a court order (eg by issuing civil proceedings against the Member) or an award of an arbitrator. $^{20}$

- Is there an existing (unsatisfied) court judgment against the Member? If not, it is doubtful that any the power of the trustees under the scheme rules to decide questions or matters of doubt is enough to constitute it as an arbitrator for this purpose.

\section{(C) David Pollard}

\section{References}

1 For an example in relation to an unapproved arrangement see Parlett v. Guppys (Bridport) Ltd [1999] OPLR 309 (CA). In this case the employer sought to set off a costs claim against the ex-employee against a pension payment due from the employer. The Court of Appeal held that this was prohibited by section 91, PA 1995.

2 See regulations 8(1), (1A) and (2) of the Occupational Pension Schemes (Assignment, Forfeiture, Bankruptcy etc.) Regulations 1997 (SI 1997/785).

3 However, note the decision of Arden J in Norman $v$. Pensions Ombudsman [1997] OPLR 85. Arden J upheld forfeiture of a member's benefit in effect for failure to repay a loan. Here the employee had purported to charge his benefits as security for loans owed to the employer and another company (the employer's parent company).

4 See for example the decision of the Court of Appeal in Antonelli v. Secretary of State for Trade and Industry
[1998] 1 All ER 997 holding that the phrase in the Estate Agents Act 1979 'an offence involving fraud or other dishonesty or violence' was wide enough to cover offences outside the UK. The court used a purposive approach

5 For an example of this in a different context see the decision of Ferris J in Mander $v$. Evans [2001] All ER (D) 185 (May), a case on the meaning of the term 'fraud' in the Insolvency Act.

6 But see further below in relation to unapproved schemes.

7 The recent analysis by the House of Lords in the National Grid case, International Power v. Healy [2001] UKHL 20; [2001] 2 All ER 417, limiting the ambit of such a restriction probably still does not allow such an amendment (even though it would not be a taxable payment - see below). For an example of the limits on such a purposive construction see Rimer $\mathrm{J}$ in Harwood-Smart $v$. Caws [2000] OPLR 227; [2000] PLR 101.

8 See para 96 of OPB Memo 78.

9 Or section 74 of the Bankruptcy (Scotland) Act 1985.

10 Contrast the position under regulation 12 of the Occupational Pension Schemes (Preservation of Benefit) Regulations 1991 (SI 1991/167, as amended). That regulation allows transfers without consent where the two schemes 'apply to employment with the same employer' etc. This looks wider in allowing a transfer where there is some connection — see Blackburne J in Merchant Navy Ratings Pension Fund Trustees v. Chambers [2001] PLR 137 at paras 41 to 49.

11 Philip Sutton kindly provided the author (some time ago) with a copy of a letter from the DSS to that effect written in August 1997.

12 There is no guidance on this in the old OPB Memo 78.

13 See the paper by Ian Greenstreet at the 1998 OPLR conference.

14 Note that it does not generally apply to unapproved schemes - see regulation 8(3) of the Occupational Pension Schemes (Assignment, Forfeiture, Bankruptcy etc.) Regulations 1997 (SI 1997/785).

15 See Mark Grant's commentary to Norman v. Clarke in [1997] OPLR 85 at p. 96.

16 Formerly 40 per cent. Reduced to 35 per cent by the Finance Act 2001.

17 Available on Lexis. Discussed in the September 1994 issue of Legal Business.

18 Check the rules and also note section 91(6)(b), PA 1995 which requires that 'the person in question must be given a certificate...'

19 There is no time limit during which the Member must raise any dispute. In practice, once the Trustee is happy that the Member actually received the notice and has had a reasonable time to respond (say 14 days?) the charge should be enforced.

20 This is a requirement under section 91(6). 